\title{
Analysis of Cement Market in Northern Nigeria
}

\author{
Abdul Ganiyu Femi Sumaila ${ }^{1}$ \\ ${ }^{1}$ Department of Transport Management Technology, Federal University of Technology, Minna, Nigeria \\ Correspondence: Abdul Ganiyu Femi Sumaila, Department of Transport Management Technology, Federal \\ University of Technology, Minna, Nigeria. E-mail: drsumaila56@yahoo.com
}

Received: October 26, 2012 Accepted: November 7, 2012 Online Published: January 11, 2013

doi:10.5539/ijms.v5n1p34 URL: http://dx.doi.org/10.5539/ijms.v5n1p34

\begin{abstract}
This paper examines the nature of cement market in Northern Nigeria, describing in details its characteristic features. Information based on two field activities, first to the cement companies' and second to thirteen market centres which permitted interaction with 54 cement sellers provided the required data for the study. The analysis of the data reveals that $90 \%$ of cement sold is bagged while the remaining is sold in bulk. The paper also reveals that four cement brands are visible in the market with Dangote brand enjoying about $60 \%$ of the market share. Construction Companies, Block-making industries, Building contractors and individuals constitute the main cement buyers in Northern Nigeria. Based on these findings, and given the general high prices of cement brands in the country, the paper recommends the need for the cement companies to increase their production capacities and also begin to focus more on the production of Cem 1(42.5) in line with global development in cement production.
\end{abstract}

Keywords: market competition, brand visibility, market segmentation, market promotions

\section{Introduction}

Human activities have today become not only increasingly dependent on the market, but are greatly influenced by it. For mechanical transformation activities such as manufacturing, the market is key, determining the pace of production and shaping the direction of operation (Barnes, 1989). In the past, people saw the market simply as a location-based activity, a place where people met to buy and sell. But today it has become a phenomenon, a process of buying and selling. Indeed, it is a process of going through established channels to render a service which has a value-added benefit for the consumer (Ndikon, 2008)

Barnes (1989) sees market as a mix of four Ps (the product, place, price and promotions) which classify all the resources available to a company in the planning and controlling of its marketing operations. These four components must not be viewed as separate functions but as relating independently. Any decision the company takes on product type such as dimension, weight or fragility very much affects the product price and the market you take it to. So also, promotional campaigns mounted to boost sales in the short-term must be planned having considerations for all the other components of the market.

Thus, according to Sumaila, (2001), a well defined and operated market would achieve the following:

i. Near elimination of out-of-stock occurrences through accurate inventory placement and control.

ii. Shortened customer order cycles and consequent reduced customer inventories.

iii. Solidification and perpetuation of supplier's relationship with its customers by integrating supplier's delivery facilities with the customer's receiving facilities and the consignment of stocks to the customers.

iv. Increased delivery discounts to customers.

v. Permission of more profitable competition leading to greater market penetration and expansion of market territories.

The strategic role of markets in the production process has driven many industrial concerns to locate right in the heart of their markets. Though most cement factories are location dispersed from the market, they, like other industries, cannot survive without the existence and operations of viable markets. Indeed, it has become increasingly obvious that cement companies must develop a marketing culture in order to respond effectively to consumer demand and changing commercial environment. This becomes even more critical in an increasingly 
competitive business environment and particularly in developing economies.

Soares (2006) observed that there is little occurrence of foreign trade in the cement market of Brazil. According to him, the market is concentrated in the most developed regions of the south, southeast, and northeast with such segments as Buildings (78\%), Infrastructure (10\%), and Agriculture (3\%) as the main end-users.

The Competition Commission of Mauritius (2011) carried out a study of the cement market in the country. The study which was to understand the condition of competition in the market revealed that the market was highly concentrated with a risk of cartelization and price collusion. The study observed that competition in the market was constrained by state interventions, mainly by deterring new entry, preventing expansion of existing companies and restricting cement to only one variety. The study therefore recommended that price and import liberalization will result in more conducive environment for new entry and increased competition in the cement market.

Dhole (2011) carried out a comprehensive study of Indian cement industry. He argues that because cement is a highly freight-sensitive product (i.e high-bulk and low-value), the Indian cement market is largely a regional one. This according to him means that the demand-supply dynamics would be different for the various regions and the country as a whole.

In Nigeria, the cement business is fast growing not only in terms of production capacity and volume driven in the market, but also in terms of plant sophistication and product variety and quality. The pace of socio-economic development in the country is responsible for this transformation. Domestic consumption has multiplied resulting in the establishment of additional cement factories across the nation. This has introduced competition which is not only challenging the distribution systems of cement companies, but also restructuring the cement market in the country. Nowhere is the scramble for market and product competition more pronounced and visible than in the Northern part of Nigeria where cement business is experiencing a boom.
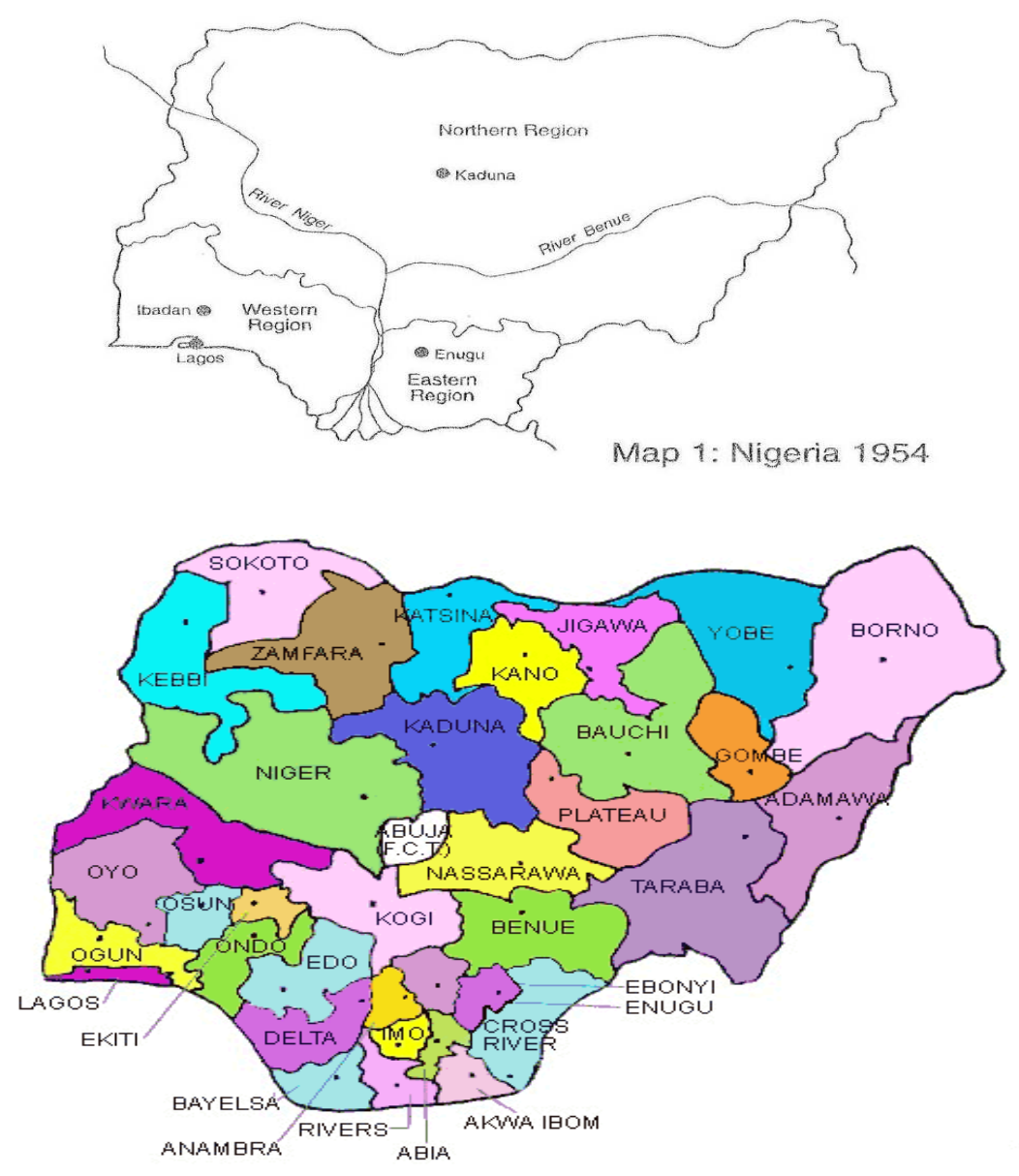

Figure 1. Regions and states of Nigeria 
Northern Nigeria is that large bowl-shaped region defined and carved out by the boundaries of Kwara, Kogi, and Benue States as its southern limits and stretching across the east-west dimensions of the Nigerian geographical space (see Figure 1). It comprises the Federal Capital Territory (FCT) and nineteen (19) of the thirty-six (36) states of the Federation. It covers about two-thirds of Nigeria's land space and houses four of the six major cement factories in Nigeria. These factories collectively produce about 14 million out of the 23 million metric tons of cement currently produced annually in the country. With a population of about 90 million people, Northern Nigeria constitutes about $60 \%$ of Cement Sales Market in Nigeria.

Given this competitive setting, it becomes imperative to know how the companies are coping and faring in the market especially with regard to meeting the needs of their customers. Thus, in order to survive, have competitive edge in the market, and enhance customer loyalty, the companies must therefore of necessity carve out their own market niches which they must hold, control and protect. It is from this perspective that this paper examines the cement market in Northern Nigeria, describes its nature, and provides details of its characteristic features.

\section{Methodology}

Data for this study was based on two field activities. It started with visits to the cement companies located in northern Nigeria namely Dangote cement plants in Obajana and Gboko; Sokoto Cement Company and Ashaka-Lafarge Company. The visits enabled the collection of comparable information and bench-marking data relating to the following:

i. Bulk- Purchase customers

ii. Company's Distributorship system

iii. Costs of Authority to Collect (ATC)

iv. Promotional Activities

Information from the companies also provided the basis for the field visits to different market centres in Northern Nigeria.

Table 1. Selected market centres visited

\begin{tabular}{ll}
\hline Regions & Centres \\
\hline \multirow{3}{*}{ North East } & Maiduguri \\
& Jalingo \\
& Damaturu \\
& Yola \\
& Mubi \\
& Bauchi \\
& Gombe \\
North West & Kano \\
& Katsina \\
& Kaduna \\
North Central & Zaria \\
& Jos \\
& FCT \\
\hline
\end{tabular}

The selection of the centres was based essentially on the possibility of obtaining comparable information on different brands of cement. Consequently, Thirteen (13) market centres located in the three geo-political zones in the North were therefore selected and visited.

A total of 54 cement sellers selected randomly in the market centres were interviewed and interacted with. The random selection was simplified by the fact that virtually all cities in northern Nigeria have designated cement markets most cases in the Railway stations. It was therefore possible to meet all the sellers in one area in each town making selection of sampled sellers very simple and systematic. The interactions permitted the recording of information on the following:

i. Brands Sold

ii. Volumes Driven in 2011\& 2012

iii. Source and mode of Cement Purchase 
iv. Preference of Market Segments

v. Cost of ATC (Authority to Collect) for each brand

vi. Landing Costs

vii. Selling prices

viii. Profit Margins

ix. Brand Market share

x. Customer Concerns and Complaints.

Information obtained through these exercises were analysed and the results exhaustively discussed in the paper.

\section{Characteristic Features of Cement Market}

\subsection{Structure of the Market}

Generally, cement produced in Nigeria in sold either in bulk or in bags. Presently in northern Nigeria, only about $10 \%$ of cement sales is in bulk, while the remaining $90 \%$ is sold in bags. Construction companies buy cement directly from the plants using bulk tankers. Such companies operating in the north include Julius Berger, Sarplast, Public Works (PW) and Dantata and Sawoe among others. These companies patronize in particular Dangote factory in Obajana buying about $10 \%$ of the company' total production, and Ashaka plant where they buy $5 \%$ of its production volume. These companies are regarded as Contract Customers and Key Accounts holders who are given not only premium price but also allowed credit purchases.

On the other hand, bagged cement is sold essentially through designated buyers known officially as company distributors. They buy cement through two main methods. The first called the "delivered method" provides that sales orders and payments are made to cover the costs of cement and transportation such that the products are delivered directly to the customers. The second method known as "self collect system" allows orders and payments to be made for cement only while the customers handle the transportation of the products.

For all the companies studied, distributors are currently categorized based on these two sales methods ie as 'Self-Collect' and 'Delivered' customers. Due to the fluid nature of the distributorship systems, the actual number of Distributors for each company could not be ascertained. For instance, Dangote Company registers any customer who buys as low as one truck (40 tons) as a Distributor, while the Ashaka system is also open to all. Today, Dangote has close to two thousand (2000) customers in the north, while Ashaka has about five hundred (500). The status of a Distributor is determined by the volume he drives. However, all the companies are presently restructuring their distributorship systems.

\subsection{Brand Visibility and Market Competition}

In Northern Nigeria, four brands of cement are highly visible. These are: Dangote, Ashaka, Sokoto and Bua brands. Competition in the market therefore varies within and between the states. In a state like Katsina, Dangote is the only competing brand. In some others such as Kaduna, Kano, and the FCT, the competing brands are not less than three (Dangote, Sokoto, and Bua) while two competing brands (Dangote and Bua) are visible in the remaining selected states (See Table 2)

Table 2. Market competitors

\begin{tabular}{|c|c|c|c|c|c|c|c|c|c|c|c|c|c|c|c|c|}
\hline \multirow[b]{2}{*}{ LOCATION } & \multicolumn{4}{|c|}{ LANDING PRICE } & \multicolumn{4}{|c|}{ SELLING PRICE } & \multicolumn{4}{|c|}{ MARGIN (\%) } & \multicolumn{4}{|c|}{$\begin{array}{c}\text { MARKET SHARE } \\
(\%)\end{array}$} \\
\hline & 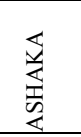 & 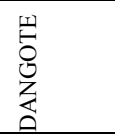 & $\overleftrightarrow{Ð}$ & $\begin{array}{l}0 \\
0 \\
o \\
o \\
\dot{o n}\end{array}$ & 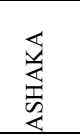 & 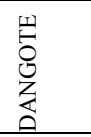 & 怘 & $\begin{array}{l}0 \\
\vdots \\
0 \\
b \\
0 \\
n\end{array}$ & 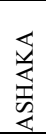 & 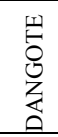 & 岕 & $\begin{array}{l}0 \\
0 \\
0 \\
0 \\
0 \\
0\end{array}$ & 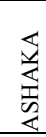 & 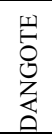 & $\overleftrightarrow{Ð}$ & $\begin{array}{l}0 \\
0 \\
0 \\
0 \\
0 \\
0\end{array}$ \\
\hline GOMBE & 1840 & 1850 & 2333.3 & NIL & 1900 & 1950 & 2400 & NIL & 3 & 5 & 3 & NIL & 70 & 25 & 5 & \\
\hline BAUCHI & 1890 & 1766.67 & 2250 & NIL & 1950 & 2000 & 2450 & NIL & 3 & 10 & 9 & NIL & 65 & 30 & 5 & \\
\hline YOLA & 1950 & 1833.33 & 2350 & NIL & $\begin{array}{l}2050 / \\
2100\end{array}$ & $\begin{array}{l}2000 / \\
2050\end{array}$ & 2550 & NIL & 8 & 12 & 9 & NIL & 75 & 15 & 10 & \\
\hline MUBI & 1950 & 1900 & 2350 & NIL & 2100 & $\begin{array}{l}2000 / \\
2100\end{array}$ & 2450 & NIL & 8 & 11 & 4 & NIL & 75 & 15 & 10 & \\
\hline
\end{tabular}




\begin{tabular}{|c|c|c|c|c|c|c|c|c|c|c|c|c|c|c|c|c|}
\hline JALINGO & 1800 & 1783.33 & 2283.3 & NIL & 2000 & 2000 & 2450 & NIL & 11 & 12 & 8 & NIL & 5 & 85 & 10 & \\
\hline $\begin{array}{c}\text { DAMATUR } \\
\text { U }\end{array}$ & 1945 & 1850 & 2250 & NIL & 2000 & 1900 & 2400 & NIL & 3 & 5 & 7 & NIL & 60 & 30 & 10 & \\
\hline \multirow[t]{2}{*}{ MADUGURI } & 1760 & 1900 & 2250 & NIL & 1800 & 1950 & NIL & NIL & 8 & 5 & NIL & NIL & 15 & 85 & & \\
\hline & & & & 1920 & & 1950 & & & & & & & & & & \\
\hline \multirow[t]{2}{*}{ KADUNA } & 1850 & 1677 & 2250 & 1820 & 1950 & 1950 & 2400 & 2100 & 8 & 16 & 7 & 15 & 5 & 80 & 5 & 10 \\
\hline & & & & 1700 & & 1800 & & & & & & & & & & \\
\hline KANO & 1950 & 1800 & 2300 & 1920 & 2000 & 1900 & 2450 & 1950 & 3 & 6 & 7 & 11 & 5 & 80 & 10 & 5 \\
\hline JOS & 1880 & 1850 & 2200 & NIL & 1900 & 2000 & 2400 & NIL & 4 & 8 & 9 & NIL & 2 & 97 & 1 & \\
\hline KASTINA & 1950 & 1800 & 2350 & NIL & 2000 & 1900 & 2450 & NIL & 3 & 6 & 4 & NIL & 0 & 100 & 0 & 0 \\
\hline ABUJA & 1720 & 1606 & 2250 & 1750 & 1850 & 1850 & 2400 & 2100 & 8 & 15 & 7 & 11 & 10 & 80 & 5 & 5 \\
\hline
\end{tabular}

Source: Field Survey, May, 2012

But generally, in all the states, the most dominant brand is Dangote cement enjoying about $60 \%$ of the market share of northern Nigeria. While its Benue brand is popular in the Northeastern states especially (Taraba and Bornu) the Obajana brand is highly visible in the FCT, the North central (Kogi, Plateau, and Niger) and North western states (Katsina, Kano, Kaduna). Ashaka cement ranks second having over $25 \%$ share of the northern market. It is visible in all the states except Katsina. But its dominance is highest in its base, the Northeastern region especially states of Gombe, Bauchi, Adamawa, Taraba, and Yobe where it enjoys a market share of about $70 \%$. Thus, Ashaka cement can therefore be said to operate within a traditional comfort zone, enjoying local monopoly. Most buyers claim not to know no other companies for business having pathological obsession and passion for Ashaka cement as the source of their wealth. There is also ethnic and regional attachment to the company as it is perceived and seen as the property of the north.

Bua cement, an imported product based in Port Harcourt is also visible in many states of the North though in smaller proportions compared to Dangote and Ashaka brands. The brand has about 10\% share of the market mostly in the Northeastern and Northwestern parts. Sokoto cement is the least visible. Outside Sokoto state, small quantities could be found in Kaduna and Kano states, and the Federal Capital Territory. Its share in the Northern market is about 5\%. It can therefore be concluded that in terms of market territories, while Dangote controls the North central and Northwestern parts, Ashaka cement has its stronghold in the Northeast.

\subsection{Cement Prices and Brand Viability}

Generally, cement prices are skyrocketing in the country. The current cost of an Authority to Collect (ATC) for 30 tons of cement ranges from $\# 835,000$ for Dangote and \#951,000 for Ashaka and \#2,050.00 for Bua cement. The high cost of ATC for Bua is understandable. Apart from being an imported product, it is of the $42.5 \mathrm{Cem} 1$ grade which is of higher quality than the local products which are generally of the Cem ii type of 32.5 .

The cost of transporting the products to the markets combined with the ATC produced the landing prices as shown in (Table 2). In all the states, the landing costs of Dangote brands are the lowest while Bua has the highest. Apart from differences in the costs of ATC, the cost of transporting cement from the North to the South is generally high in the country. This situation has therefore resulted in high prices of cement in all the states as reflected in the selling prices which range from $\# 1,800.00$ per bag of Ashaka cement in Maiduguri and Kaduna to \#2550 per bag of Bua brand in Yola. The high price differential of Ashaka cement in many states is due in part to the involvement of many middlemen in the distribution chain.

With regard to brand viability, Dangote presents the most favourable business returns to its customers. In all the states with the exception of Bornu, the percentage margins made by Dangote customers are higher than those of other competitors (See Table 2). In all the states, while Dangote customers make an average of $9 \%$ profit margin, it is $6 \%$ for Bua and about $5 \%$ for Ashaka customers. In a state like Bauchi, the margin for Dangote is three times higher than that of Ashaka while in most of the other states, Dangote is twice higher. In the same vein, Sokoto cement and even Bua customers also enjoy higher margins than those of Ashaka cement.

\subsection{Market Segmentation}

Four major segments of the market use cement products in Northern Nigeria. Presently, Construction Companies operating in Northern Nigeria, Block-making industries, Government and Private Building Contractors and 
Individuals constitute the cement buyers in Northern Nigeria. (See Table 3)

Table 3. Preference of market segments (in percentages)

\begin{tabular}{llllll}
\hline & & \multicolumn{2}{l}{ CEMENT BRANDS } & \\
S/NO & SEGMENTS & ASHAKA & DANGOTE & BUA & SOKOTO \\
\hline 1 & Construction companies & 20 & 30 & 30 & 20 \\
2 & Block-Makers & 5 & 10 & 80 & 5 \\
3 & Contractors & 50 & 30 & 5 & 15 \\
4 & Individuals & 45 & 35 & 5 & 5 \\
\hline
\end{tabular}

Source: Field Survey, May, 2012.

Generally, construction Companies use the four cement brands fairly averagely. However $60 \%$ of their needs are provided by Dangote and Bua brands. This is not surprising since Construction companies generally prefer Cem1 (42.5) which they claim is stronger and more effective compared to Cem ii (32.,5). In terms of output, what 10 bags of Cem ii would produce, only 7 bags of Cem1 would be required. As discussed earlier, Bua being an imported product is essentially Cem 1, while Dangote plant at Obajana has a line producing only Cem1. For Ashaka and Sokoto brands, construction companies demand bulk supply which these companies do not readily meet. Moreover, they complain about the grade of Ashaka product and the underweight of the bags and its constant bustages (See Figure 2). The small quantity they buy is used mainly for pre-casting and construction of chambers, while Sokoto Cement is used mainly for building of beams.

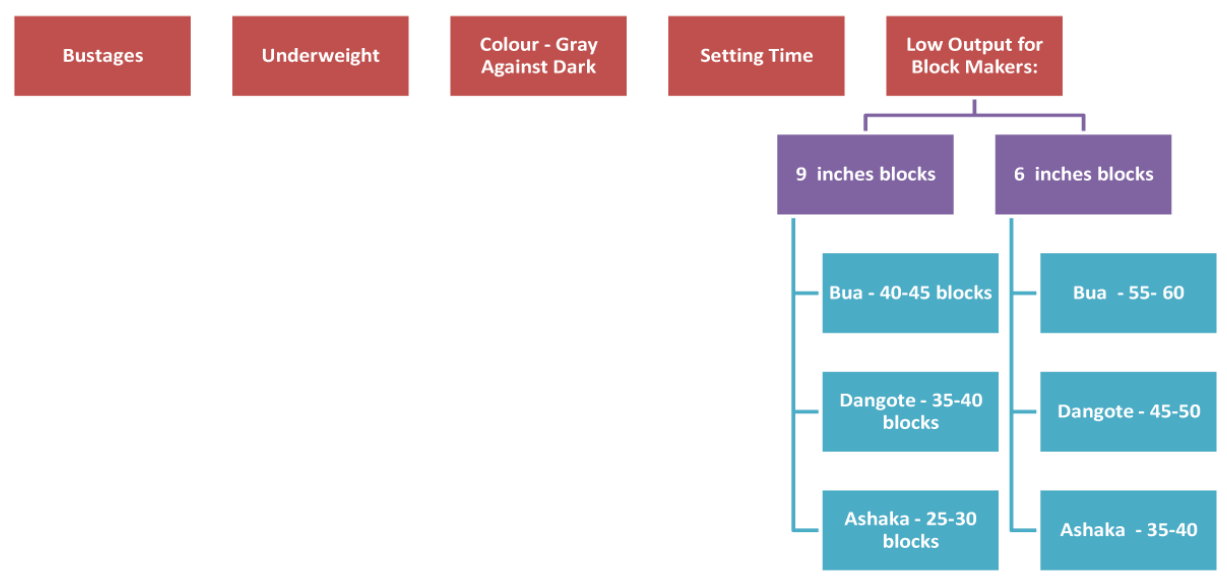

Figure 2. Quality of cement products

Block-makers in the North today depend essentially on Bua product which provides $80 \%$ of their total cement needs. They claim that Bua product yields the highest number of blocks per bag. For instance one bag of Bua yields 45 blocks of 9 inches compared to 40 from Dangote and 30 blocks from Ashaka cement. In the same vein, a bag of Bua cement produces 60 blocks of 6 inches as against 50 and 40 blocks from Dangote and Ashaka products respectively (see Figure 2).

On the other hand, Ashaka Cement and Sokoto brands are no longer popular with block-makers. One major complaint against the products especially Ashaka cement is the grey colour which gives the impression that blocks made from the product are more of sand, and thus perceived as not as strong as the dark-coloured blocks which Bua and Dangote brands produce. Indeed the little quantity of Ashaka cement used for block-making is mainly during the wet season because of its shorter setting time as it dries up faster than others.

Presently, Building Contractors and Individuals constitute the major buyers of Ashaka product representing 50\% 
and $45 \%$ of their respective needs. These groups of buyers assert that Ashaka cement is stronger than those of its competitors and thus prefer to use the product for building of their personal houses. For Sokoto cement, the product is gradually penetrating the market as all the market segments appear to be trying out the product.

\subsection{Market Promotions}

Promotions constitute an integral part of the marketing function employed by a company to convert people's genuine needs into wants, and thus inducing them to make actual purchases of the company's products (Mcintosh, 1984). Such promotional activities are evidently prominent in cement sales and thus characterize the cement market in Northern Nigeria. One of such is Rebate/ Discount on purchases which are given to different categories of Cement Distributors (See Table 4). For instance, Dangote Distributors who buy less than 200tons of Cement pay \#1,490.00 per bag as against \#1,400 per bag for quantities from 201 to 360 tons. Furthermore, 40 tons bonus is given for purchase of 2000 tons per month. Similarly, there is a difference of \#220 per bag between purchases of 300 tons and those above 1,500 tons of Bua Cement. Bonus of up to three trucks is given to customers who buy up to 200 trucks in a year. For Ashaka Cement Company, rebate was cancelled in October 2011 to allow for re-structuring of the distributorship.

Table 4. Promotional activities

\begin{tabular}{|c|c|c|c|c|c|}
\hline Companies & $\begin{array}{l}\text { Distributors } \\
\text { Categories }\end{array}$ & $\begin{array}{l}\text { Rebate/ } \\
\text { Incentives }\end{array}$ & $\begin{array}{l}\text { Lead time } \\
\text { (delivery) }\end{array}$ & Mode of payment & Promotion \\
\hline $\begin{array}{l}\text { Ashaka } \\
\text { Dangote }\end{array}$ & $\begin{array}{l}\text { Undergoing restructuring } \\
<=200 \text { tons } \\
200-360 \text { tons } \\
>400 \text { tons }\end{array}$ & $\begin{array}{l}\text { None } \\
\mathrm{N} 1,490 \text { per bag } \\
\mathrm{Ni}, 400 \text { per bag } \\
\mathrm{N} 1,395 \text { per bag } \\
\text { ( } 40 \text { tons bonus for } \\
\text { purchase of } 2000 \\
\text { tons per month) }\end{array}$ & $\begin{array}{l}\text { Over } 30 \text { days } \\
3 \text { days }\end{array}$ & $\begin{array}{l}\text { Bank draft } \\
\text { Bank transfer }\end{array}$ & $\begin{array}{l}\text { Nil } \\
\text { *provision supplied } \\
\text { to customers during } \\
\text { Ramadan } \\
\text { * damages are } \\
\text { picked and replaced } \\
\text { immediately } \\
\text { * arranges end - of } \\
\text { the year dinner for } \\
\text { customers with gifts. } \\
\text { * award to super } \\
\text { distributors e.g n10 } \\
\text { m cash/vehicles }\end{array}$ \\
\hline Bua & $\begin{array}{l}30-300 \text { tons } \\
300-1500 \text { tons } \\
>1500 \text { tons }\end{array}$ & $\begin{array}{l}\text { N } 1,920 \text { per bag } \\
\text { 1 } 1,820 \text { per bag } \\
\text { 1 } 1,700 \text { per bag }\end{array}$ & 7 days & Bank transfer & \\
\hline Sokoto & Undergoing restructuring & $\mathrm{Na}$ & 7 days & Bank transfer & \\
\hline
\end{tabular}

Source: Field Survey, May, 2012

System, while Sokoto Cement is currently working on its rebate system.

Dangote Customers also benefit from a wide range of promotional activities such as provisions during festivities and gifts of cash and vehicles to Super Customers. The company also organizes Annual End of Year Get-together for all customers which is attended personally by the President of Dangote Cement Company. All these are currently not part of the sales and marketing packages of other cement Companies visible in the North. It is therefore not surprising that Dangote Cement Company has become the "Market Leader" in Northern Nigeria.

\section{Conclusion}

We have shown in this paper the critical role of markets in cement business in Nigeria. We have in particular examined the nature of cement market in Northern Nigeria describing in details its characteristic features. We have shown that $90 \%$ of the cement sold is bagged while the remaining is sold in bulk. The paper also revealed that cement prices are generally high in Nigeria especially in the north. The strong presence of middlemen in the market chain and the inadequate capacities of the companies are responsible for this disturbing scenario. Four cement brands are highly visible in the market with Dangote brand enjoying about $60 \%$ of the market share. It is also the most viable presenting the most favourably business returns to its customers. In terms of market segmentation, Construction Companies, Block-making industries, building contractors and individuals constitute 
the cement buyers in Northern Nigeria. Only Dangote Cement Company employs promotional activities as part of its sales package.

From the study, Dangote Cement Company has assumed the role of a 'Market Leader' in Northern Nigeria. But all the companies without exception are active participants in the market. The market is evidently segmented not only into territories, but also among buyers. This result conforms with expectations in the literature as all the companies have created their market niches which they jealously control and protect.

It is also evident from the study that the market is far from being saturated. Most buyers complained of scarcity of products forcing them to sell all brands in order to remain permanently in the market. This implies that the companies must of necessity increase their production capacities. This is particularly expedient in order to bring down the prices of cement brands in the country. Ashaka Cement has a plant capacity of 850,000 tons which it hardly meets, while Sokoto Cement produces presently at less than $50 \%$ installed capacity.

It is also recommended that the companies should join the new trend in global cement production by focusing more on Cem 1(42.5) which is of higher quality than the present grade produced generally in the country. This would satisfy the demands of Construction Companies and block-makers and consequently reduce importation of cement.

On the whole, the cement business is surely a lucrative one. Given its potentials to provide employment for large number of Nigerians, the current Government support for the industry should be sustained. The market has the capacity to provide a major source of livelihood to many Nigerians the multiplier effects of which hold the promise of a major transformation of the Nigerian economy.

\section{Acknowledgements}

The Author acknowledges the support of Micromab and Linkage Logistics Services especially Dr Mike Bello who participated in the field activities. The technical assistance provided by Florence Anozie and Tinuke Sumaila are equally appreciated.

\section{References}

Barnes, C. (1989). Successful Marketing for the Transport Operator. Kogan Page Ltd, London.

Competition Commission of Mauritius. (2011). Study of the Market for Cement in Mauritius' Official Report, $12^{\text {th }}$ April, 2011.

Dhole, M. (2011). Comprehensive Study of Indian Cement Industry. Commerce, 1(5).

McIntosh, D. (1984). Marketing: A Handbook for Charities, Directory of Social Change. London.

Ndikom, O. B. C. (2008). Elements of Transport Management. Bunmico Publishers, Nigeria, pp 408-420.

Soares, J. (2006). Section V. A. Sector Analysis and Results: Cement Industry in Green House Gas Mitigation in Brazil: Scenarios and Opportunities through 2025; Centre for Clean Air Policy, Nov. 2006.

Sumaila, A. G. (2001). Marketing in Transport. Paper presented at the Transport. 